\title{
ABUNDANCE AND DIVERSITY OF MITES ( ACARI ) ASSOCIATED WITH THE RED PALM WEEVIL, RHYNCHOPHORUS FERRUGINEUS (OLIVER) IN ISMAILIA GOVERNORATE, EGYPT
}

\author{
EL-KADY, G. A' ${ }^{1}$, T. A. SALMAN2 ${ }^{2}$ M. K. ABBAS ${ }^{2}$ and \\ H. M. EL- SHARABASY1 \\ 1. Plant Protection Dept., Faculty of Agriculture, Suez Canal University, Ismailia, \\ Egypt. \\ 2. Plant Protection Research Institute. ARC, Dokki, Giza. Egypt.
}

(Manuscript received 30 August 2016)

\begin{abstract}
$\mathrm{T}$ he red palm weevil, Rhynchophorus ferrugineus (Olivier) (RPW) is an economically important pest of palm trees in Egypt especially in Ismailia Governorate. Very few studies have been conducted on mites as natural enemies of red palm weevil. The predaceous and parasitic mites play an important role as biological agents of RPW. The survey of mites with different stages of RPW in Ismailia revealed 1197, 673 and 162 individuals with 120 empty cocoons, 53 larvae and 75 adults of RPW, respectively. A total of eleven mite species belong to 9 families and 4 suborders were found associated with the red palm weevil, $R$. ferrugineus. Family Uropodidae was the most abundant followed by Acaridae. Most of mite species that recorded in this study are parasitic on adults and larvae of RPW. The prevalence of $T$. putrescentia was $(17.33 \%),(56.60 \%)$ and $(25.83 \%)$ with adult, larvae and empty cocoons, respectively.
\end{abstract}

Key words: Mites, Survey, Rhynchophorus ferrugineus, Biological Control, Ismailia.

\section{INTRODUCTION}

The red palm weevil Rhyncophorus ferrugineus (Oliver) (Coleoptera: Curculionidae) is an important pest of date palm trees in the Middle East and North Africa (EPPO, 2008). Among the known date palm pests, it is the most harmful, because the infestation ate often not detected until the fronds wilt and the crown collapses suddenly (Sivapragasam et al., 2010). The red palm weevil females deposit their eggs in separate holes at the base of the fronds. It spends all immature stages inside the date palm. Larvae burrow through the soft tissues of the crown forming extensive tunnels. These tunnels may cause the crown and trunk to weaken, resulting in death of the tress. The mature larvae develop in a cocoon and emerge as an adult's weevil (Murphy and Briscoe, 1999). A number of species have been recorded as natural enemies of Rhyncophorus ferrugineus, including viruses, bacteria, fungi, nematodes, insects and mites. Unfortunately, limited affect by these species was recorded on Rhyncophorus ferrugineus (Murphy and Briscoe, 1999). The relationships 
116 ABUNDANCE AND DIVERSITY OF MITES ( ACARI ) ASSOCIATED WITH THE RED PALM WEEVIL, RHYNCHOPHORUS FERRUGINEUS (OLIVER) IN ISMAILIA GOVERNORATE, EGYPT

between some of these species could have positive, or negative natural influences on the weevil, and the most least study of it are the mites.

Biodiversity of mites associated with the red palm weevil is varying degrees of biorelationship between each of the associated, ecto-, endoparasitic, predaceous, phoretic and fungivorus mites. Studies on mites associated with RPW have been reported by several authors (Gomaa, 2006; El-Bishlawy and Allam, 2007; Abd-ElHamed, 2009; El-Sharabasy, 2010; Al-Deeb et al., 2011; Hassan et al., 2011; AlDhafar and Al-Qahtani, 2012; Dilipkumer et al., 2015).

The present study aims to throw lights on mite species associated with different stages of RPW in Ismailia Governorate to determine the species composition and their distribution patterns.

\section{MATERIALS AND METHODS}

Adults of Rhyncophorus ferrugineus ( $n=75)$, larval instars $(n=53)$ and empty coccons $(n=120)$ were collected from damaged trunks of infested date palm trees, Phoenix dacylifera L. (Palmaceae), at Tal-Elkeber \& Kassasin localities, in Ismailia Governorate, during high months (May-August2012). Different collected stages of RPW were transferred in plastic boxes to the laboratory and carefully investigations. Different collected stages of (RPW) each groups of mites were separated according to its morphological character were examined individually using dissecting microscope, whereas, detecting mites were removed gently with fine brush then mites were counted, cleared in Nesbitt's solution and mounted in Hoyer's medium for identifications. Mite specimens were identified according to Krantz (1978) \& Zaher (1986). Identified mites were deposited in Plant Protection Department, Faculty of Agriculture, Suez Canal University, and Ismailia, Egypt.

\section{RESULTS AND DISCUSSION}

Mites associated with different stages of the red palm weevil were listed in Table (1). Eleven mite species belong to 9 families and 4 suborders were found. The four suborders and mite families were; suborder Acaridida included two families (Acaridae and Histostomidae), suborder Gamasida included 5 families (Ascidae, Eviphididae, Laelapidae, Parasitidae and Uropodidae). Suborder Actinedida included one family (Scutacaridae), while suborder Oribatida included one family (Oppiidae). Family Acaridae included the most abundant species (Tyrophagus putrescentiae (Schrank)). 
On the other hand, family Uropodidae was the most abundant that included one species (Trichouropoda patavina (Canestrini)) and one genus (Urobovella sp.). Many uropodid mites occur commonly in litters, soil, rotting wood and nests of insects. Mesbah et al., (2008) observed that Urobovella varians Nicol found on all body regions of the adult stage of RPW as a phoretic, while Gomaa (2006) found U. krantzi associated with all stages of RPW. Family Laelapidae one species (Hypoaspis sardoa Berlese) and one genus (Cosmolaelaps sp.). While, Gomaa (2006) found Hypoaspis queenslandicus (Womersly) associated with all stages of the red palm weevil in Sharkia Governorate.

Table 1. List of mites associated with different stages of Rhyncophorus ferrugineus at Ismailia Governorate.

\begin{tabular}{|c|l|c|}
\hline $\begin{array}{c}\text { Sub order } \\
\text { Families }\end{array}$ & \multicolumn{1}{|c|}{ Species } & Remarks \\
\hline $\begin{array}{c}\text { I-Acaridida } \\
\text { Acaridae } \\
\text { Histostomidae }\end{array}$ & Tyrophagus putrescentiae (Schrank) & +++ \\
\hline $\begin{array}{c}\text { Histosoma sp. } \\
\text { II-Gamasida }\end{array}$ & Proctolaelaps striatus Afifi, Hassan and ElBishlawy & + \\
\hline Ascidae & Iphidosoma sp. & ++ \\
\hline Eviphididae & Hypoaspis sardoa Berlese & ++ \\
\hline Laelapidae & Cosmolaelaps sp. & ++ \\
\hline Parasitidae & Parasitis zaheri Hafez and Nasr & ++ \\
\hline Uropodidae & Trichouropoda patavina (Canestrini) & + \\
\hline III- Actinedida & Urobovella sp. & +++ \\
\hline Scutacaridae & & + \\
\hline IV- Oribatida & Scutacarus sp. & + \\
\hline Oppiidae & & \\
\hline
\end{tabular}

$+=$ Rare (1-2 individuals/RPW) $++=$ Moderate (3-4 individuals/RPW)

$+++=$ High (more than 4 individuals/RPW)

Family Ascidae and family Parasitidae included one species for each (Proctolaelaps striatus Afifi, Hassan and El-Bishlawy and Parasitis zaheri Hafez and Nasr, respectively). This mite species was recorded for the first time as phoretic on red palm weevil by El-Sharabasy (2010). This species was occurred occasionally in few numbers moving on cocoons fibers and larval stage, but not found on adult stage. Members of family Parasitidae could have some potential for biological control of the 
118 ABUNDANCE AND DIVERSITY OF MITES ( ACARI ) ASSOCIATED WITH THE RED PALM WEEVIL, RHYNCHOPHORUS FERRUGINEUS (OLIVER) IN ISMAILIA GOVERNORATE, EGYPT

red palm weevil. Family Histostomidae, Eviphididae, Scutacaridae and Oppiidae included one genus for each. El-Sharabasy (2010) found Scutacarus $s p$ in very few numbers in cocoon fibers of RPW.

As shown in table (2), 347, 231 and 55 individuals of family Acaridae were found associated with 120 empty cocoons, 53 larvae and 75 adults of Rhyncophorus ferrugineus .

Table 2. Abundance and prevalence of mites on different stages of (RPW).

\begin{tabular}{|c|c|c|c|}
\hline Species & $\begin{array}{c}\text { Empty cocoons } \\
(n=120)\end{array}$ & $\begin{array}{l}\text { Larvae } \\
(n=53)\end{array}$ & $\begin{array}{l}\text { Adults } \\
(n=75)\end{array}$ \\
\hline T. putrescentiae & $347\left(25.83 \%^{\#}\right)$ & $231(56.60 \%)$ & $55(17.33 \%)$ \\
\hline Histostoma sp. & $37(30.83 \%)$ & $22(26.41 \%)$ & - \\
\hline P. striatus & $21(10.00 \%)$ & $17(20.75 \%)$ & $2(14.67 \%)$ \\
\hline Iphidosoma sp. & $46(10.83 \%)$ & $61(39.62 \%)$ & $5(6.67 \%)$ \\
\hline H. sardoa & $12(14.17 \%)$ & $15(16.98 \%)$ & $2(12.00 \%)$ \\
\hline Cosmolaelaps sp. & $26(21.67 \%)$ & $13(15.09 \%)$ & - \\
\hline P. zaheri & $26(20.00 \%)$ & $8(13.21 \%)$ & $3(10.67 \%)$ \\
\hline T. patavina & $326(40.83 \%)$ & $171(75.47 \%)$ & $53(40.00 \%)$ \\
\hline Urobovella sp. & $340(53.33 \%)$ & $130(62.26 \%)$ & $42(44.00 \%)$ \\
\hline Scutacarus sp. & $9(9.17 \%)$ & $3(16.98 \%)$ & - \\
\hline Oppia sp. & $7(5.83 \%)$ & $2(22.64 \%)$ & - \\
\hline
\end{tabular}

Mites existed in all empty cocoons were in much numbers than larval and adult stages. The total numbers of mites were 1197, 673 and 162 individuals associated with empty cocoons, larvae and adults of RPW, respectively.

The prevalence of $T$. putrescentia with adult weevil (17.33\%) was lower than larvae $(56.60 \%)$ and empty cocoons $(25.83 \%)$. Family Uropodidae included Trichouropoda patavina with highly abundance and the prevalence was (40.83\%), $(75.47 \%)$ and $(40 \%)$ on empty cocoons, larvae and adults of RPW respectively. Urobovella sp. was also highly abundance with prevalence $(53.33 \%),(62.26 \%)$ and (44\%) associated with empty cocoons, larvae and adults of RPW respectively. In the respect Gomaa (2006) found Urobovella krantzi, associated with all stages of the red palm weevil and it was highly abundant on pupal and adult stages. Two mite species, Hypoaspis sp. and Tetrapolypus rhynchophori Ewing (Pymotidae) have also been recorded with highly abundance infesting the adult beetles of RPW, but the status of these species as parasites is uncertain (Peter, 1989). 
The ecological roles of mites associated with $R$. ferrugineus are poorly known, and the abundance of mites in the sampling localities refers mainly to those mite species that were generally rare. However, further field and laboratory studies are required to precisely assess the feeding habits of the mites associated with $R$. ferrugineus and their potential use as bio-control agents.

\section{ACKNOWLEGEMENTS}

The authors are most grateful to Mohamed K. Bohibeh Plant Protection Department, Faculty of Agriculture, Suez Canal University, Ismailia, Egypt, for collected, clearing and mounting some mite specimens from different stages of RPW.

\section{REFERENCES}

1. Abdelhamed, D. M. 2009. Taxonomical and Biological studies on mites associated with some insects of agricultural economic importance. M.Sc. Thesis, Fac. of Agric., Ain Shams Univ., 147pp.

2. Al-Deeb, M.A.; Muzaffar, S.; Abuagla, A.M and Sharif, E.M. 2011. Distribution and abundance of phoretic mites (Asitigmata, Mesostigmata) on Rhynchophorus ferrgineus (Coleoptera: Curculionidae). Fla. Entomol., 94:748-755.

3. Al-Dhafar, Z. M. and Al-Qahtani, A. M. (2012). Mites associated with the red palm weevil, Rhynchophorus ferrugineus Oliver in Saudi Arabia with adescription of new species. Acarines, 6: 7-13.

4. Al-Dhafar, Z.M., Al-Qahtani, A.M., 2012. Mites associated with the red palm weevil, Rhynchophorus ferrugineus Oliver in Saudi Arabia with a description of a new species.Acarines 6, 3-6.

5. Dilipkumar, M. ; Ahadiyat, A. ; Masan, P. and Chuah, T. S. (2015). Mites (Acari) associated with Rhynchophorus ferrugineus (Coleoptera: Curculionidae) in Malaysia, with a revised list of the mites found on this weevil. Journal of AsiaPacific Entomology., (18): 169-174.

6. El-Bishlawy, Shahira M.O. and Sally F. Allam. 2007. Aegyptus rhynchophorus (Acari:Uropodina:Trachuropodidae) from the red palm weevil Rhynchophorus ferrgineus (Oliv.) (Coleoptera: Curculionidae) in Egypt. Proc. $2^{\text {nd }}$ Inter. Conf. Ent. Soc.Egypt, Vol., 1:421-433. 

RHYNCHOPHORUS FERRUGINEUS (OLIVER) IN ISMAILIA GOVERNORATE, EGYPT

7. El-Sharabasy, H.M. 2010. A Survey of mite species associated with the red palm weevil Rhyncophorus ferrugineus (Olivier) in Egypt. Egypt J. Biol. Control, 20:6770.

8. Eppo (European and Mediterranean Plant Protection Organization) 2008. Data sheets on quarantine pests. Rhyncophorus ferrugineus. Eppo Bull., 38:55-59.

9. Gomaa, W.O. 2006. Three mite species associated with the red palm weevil, Rhynchophorus ferrgineus (Oliv.) in Egypt. Bull. Fac. Agric., Cairo Univ., 57(3): 543-548.

10. Hassan, M.F., Nasr, A.K., Allam, S.F., Taha, H.A., Mahmoud, R.A., 2011. Biodiversity and seasonal fluctuation of mite families associated with the red palm weevil, Rhynchophorus ferrugineus Oliver (Coleoptera: Curculionidae) in Egypt. Egypt J. Biol. Pest. Control 21, 317-323.

11. Krantz, G.W. 1978. A Manual of Acarology. Oregan State University Book Stores, Corvallis, USA, $509 \mathrm{p}$.

12. Mesbah, H.A.; Darwish, E.T.E; Salem, S.E. and Zayed, T.M. 2008. Associations of three gamasid mite species with the red palm weevil, Rhynchophorus ferrgineus (Oliv.) in infested date palm farms in Beheira, Egypt. Minufiya J. Agric. Res., 33(6):1543-1551.

13. Murphy, S.T. and Briscoe, B.R. 1999. The red palm weevil as an alien invasive: biology and the prospects for biological control as a component of IPM. Biocontrol News Inf. 20:35-46.

14. Peter, C. 1989. A note on the mites associated with the red palm weevil, Rhynchophorus ferrgineus (Oliv.) in Tamil Nadu. J. Insect Sci., 2,160-161.

15. Zaher, M. A. 1986. Survey and ecological studies of phytophagous, predaceous and soil mites in Egypt. Final report PL 480, Programme USA Project No. EG. ARS-30, grant No.FG-139. Faculty of Agriculture, Cairo University. 


\section{تنوع واتتشار الأكاروسات المصاحبة لسوسة النخيل الحمر اء في محافظة الاسماعيلية - مصر}

جمال عبد الستار القاضي' ، طارق أحمد عبده سالمان' ، محد كمال عبد اللطيف عباس ‘ ،

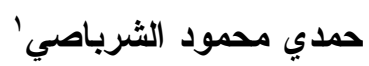

$$
\text { r r . . قعم وقاية النبات - كلية الزراعة- جامعة قناة السوبس - الاسماعبلية - مصر. }
$$

تعتبر سوسة النخيل الحمر اء واحدة من أهم الآفات الاقتصادية التي تصيب نخيل البلح في

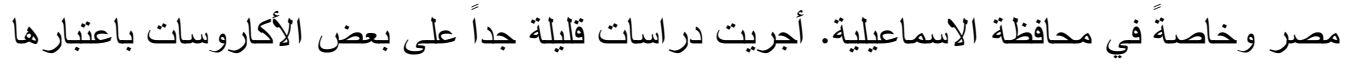
أحد الأعداء الطبيعية لسوسة النخيل الحمراء ، حيث تلعب الأكاروسات المفترسة و المتطفلة دوراً

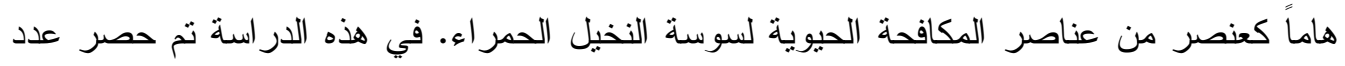

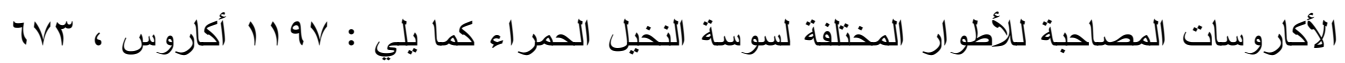
أكاروس ، و ب rا أكاروس مصاحبين لكلاً من : الثر انق الفارغة ، اليرقات ، و الحشر ات الكاملة

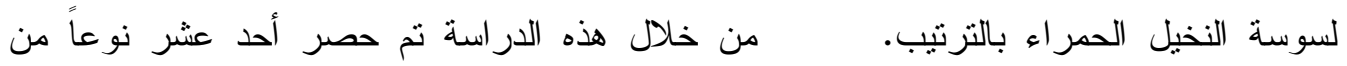
الأكاروسات تتنمي الى تسعة عائلات وأربعة تحت رثب مصاحبةً للأطو ار المختلفة لسوسة النخيل

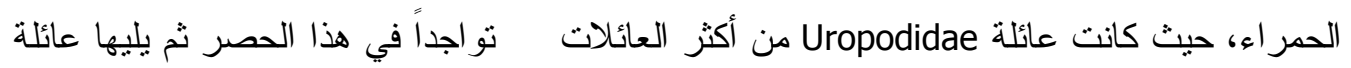

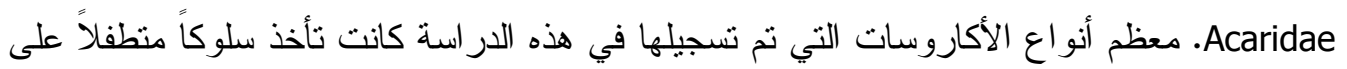

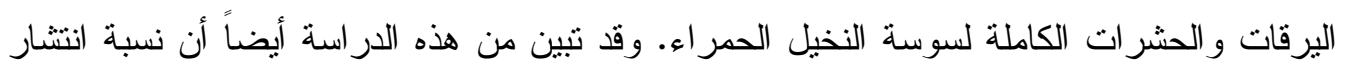

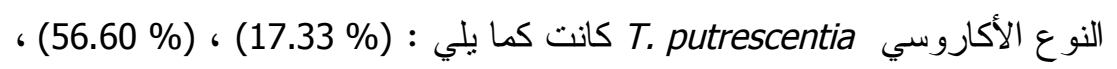

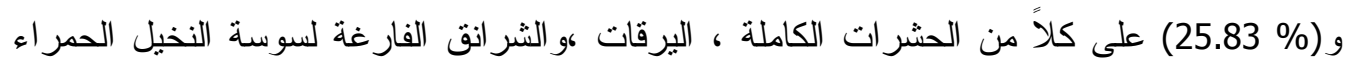

